\title{
Ammonia formation over supported platinum and palladium catalysts
}

Emma Catherine Adams*a ${ }^{* a}$ Magnus Skoglundh ${ }^{\mathrm{a}}$, Milica Folic $^{\mathrm{b}}$, Eva Charlotte Bendixen $^{\mathrm{b}}$, Pär Gabrielsson $^{\mathrm{b}}$, Per-Anders Carlsson $^{\mathrm{a}}$

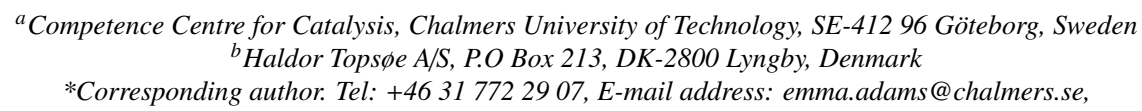

\begin{abstract}
We report experimental results for the formation of ammonia from nitric oxide and hydrogen, and from nitric oxide, water and carbon monoxide over silica, alumina and titania supported platinum and palladium catalysts. Temperature programmed reaction experiments in gas flow reactor show a considerable formation of ammonia in the temperature range $200-450{ }^{\circ} \mathrm{C}$, which is suppressed by the presence of excess oxygen. However, oxygen sweep experiments show that for the titania supported catalysts minor amounts of oxygen promotes the ammonia formation at low temperatures. In situ DRIFT spectroscopy measurements indicate that cyanate species on the support play an important role in the ammonia formation mechanism. This work shows that alumina supported palladium is a promising system for passive selective catalytic reduction applications, exhibiting low-temperature activity during the water-gas-shift assisted ammonia formation reaction. Conversely, titania supported samples are less active for ammonia formation as a result of the poor thermal stability of the titania support.
\end{abstract}

Keywords: Catalytic exhaust aftertreatment, Passive-SCR, $\mathrm{NO}_{x}$ reduction, In situ DRIFT spectroscopy, $\mathrm{NH}_{3}$ formation, $\mathrm{Pt}$, $\mathrm{Pd}$

\section{Introduction}

Combustion of petrol and diesel in vehicles results in the formation of harmful products, including nitrogen oxides $\left(\mathrm{NO}_{x}\right)$, which are known to be responsible for various environmental issues such as photochemical smog and acid rain [1, 2]. At present, the fuel economy of passenger cars can be improved by ensuring that the combustion takes place in the presence of excess oxygen, so-called lean operation [3]. Practically, lean operation makes it challenging to reduce $\mathrm{NO}_{x}$ to $\mathrm{N}_{2}$ over the conventional three-way catalyst [4]. Thus it is necessary for new strategies to be developed whereby the fuel economy can be improved whilst the tailpipe emissions are kept sufficiently low $[5,6]$. Selective catalytic reduction of $\mathrm{NO}_{x}$ with ammonia $\left(\mathrm{NH}_{3}-\mathrm{SCR}\right)$ is currently the preferred technology for $\mathrm{NO}_{x}$ abatement from stationary sources and larger vehicles includ- ing trucks and buses [7]. Ammonia-SCR relies on the ability of the catalyst to selectively reduce $\mathrm{NO}_{x}$ with $\mathrm{NH}_{3}$ to form $\mathrm{N}_{2}$ in the presence of elevated levels of $\mathrm{O}_{2}[8,2]$. However, due to concerns with the safety and toxicity associated with ammonia transportation and storage, the $\mathrm{NH}_{3}$ is stored in the form of urea-in-water solution on-board the vehicle. Urea solution is injected into the exhaust gas where it thermally decomposes and hydrolyses to form the ammonia required for $\mathrm{NH}_{3}-\mathrm{SCR}[9,10]$. Although this solution has been accepted for heavy-duty vehicles, difficulties arise when applied to smaller passenger vehicles. Some of the problems encountered are due to extra weight associated with the need for an additional urea storage tank and injection system, which is complex, costly and may affect driving performance negatively, and the risk of creating an $\mathrm{NH}_{3}$ slip $[2,4,11]$. Ammonia emissions are undesirable since $\mathrm{NH}_{3}$ is a 
toxic air pollutant and is known to contribute to the production of secondary particulate matter [12, 13].

Passive SCR is a newly developing technology that may contribute to solving some of the aforementioned problems [14]. The concept of this technique is to generate $\mathrm{NH}_{3}$ on-board the vehicle by utilizing the $\mathrm{NO}_{x}$ that is readily available in the exhaust stream whilst the engine undergoes rich operation (low air-to-fuel ratio). The formed $\mathrm{NH}_{3}$ can then be stored on an SCR catalyst downstream and used to reduce slipped $\mathrm{NO}_{x}$ when the engine is set back to operate under lean conditions. If sufficient amounts of $\mathrm{NH}_{3}$ can be produced during the rich periods and stored for complete reaction with $\mathrm{NO}_{x}$ to form $\mathrm{N}_{2}$ during the subsequent lean periods, an external urea injection system may not be needed. It is well known that $\mathrm{NH}_{3}$ can be formed over precious metal catalysts by the reaction between $\mathrm{NO}_{x}$ and $\mathrm{H}_{2}$ provided that the stoichiometric requirement, i.e. $\mathrm{H}_{2} / \mathrm{NO} \geq$ 2.5 , is fulfilled. The overall reaction follows;

$$
\mathrm{NO}+\frac{5}{2} \mathrm{H}_{2} \rightarrow \mathrm{NH}_{3}+\mathrm{H}_{2} \mathrm{O}
$$

If the criterion on the $\mathrm{H}_{2} / \mathrm{NO}$ ratio is not fulfilled, selectivity to other nitrogen-containing products has been observed $[11,15$, 16], for example $\mathrm{N}_{2} \mathrm{O}$ and $\mathrm{N}_{2}$ by the two reactions:

$$
\begin{aligned}
& \mathrm{NO}+\frac{1}{2} \mathrm{H}_{2} \rightarrow \frac{1}{2} \mathrm{~N}_{2} \mathrm{O}+\frac{1}{2} \mathrm{H}_{2} \mathrm{O} \\
& \mathrm{NO}+\mathrm{H}_{2} \rightarrow \frac{1}{2} \mathrm{~N}_{2}+\mathrm{H}_{2} \mathrm{O}
\end{aligned}
$$

In automotive applications deviations in driving patterns result in conditions where the concentration of $\mathrm{H}_{2}$ present in the exhaust feed does not meet the requirement for ammonia formation for significant periods. Despite this, passive SCR may play an important role in $\mathrm{NO}_{x}$ abatement provided that a direct supply of $\mathrm{H}_{2}$ is not necessary. Carbon monoxide and water are also present in the exhausts during rich operation [17] and $\mathrm{H}_{2}$ can be formed by the water-gas-shift (WGS) reaction;

$$
\mathrm{CO}+\mathrm{H}_{2} \mathrm{O} \rightarrow \mathrm{CO}_{2}+\mathrm{H}_{2}
$$

Hence, water could be a viable hydrogen source for the further formation of $\mathrm{NH}_{3}$.

Previously Okumura et al. showed that $\mathrm{SiO}_{2}$ and $\mathrm{Al}_{2} \mathrm{O}_{3}$ supported $\mathrm{Pt}$ and $\mathrm{Pd}$ catalysts have high selectivity to form $\mathrm{NH}_{3}$ when in the presence of $\mathrm{NO}$ and $\mathrm{H}_{2}$ at temperatures between 400 and $500{ }^{\circ} \mathrm{C}$ as compared to the corresponding $\mathrm{Ir}$ and $\mathrm{Rh}$ catalysts. In addition, Macleod et al. [2] showed that there is a synergy between $\mathrm{Al}_{2} \mathrm{O}_{3}$ and $\mathrm{TiO}_{2}$ supports, which leads to further elevated formation of $\mathrm{NH}_{3}$ in the presence of $\mathrm{NO}$, $\mathrm{CO}$ and $\mathrm{H}_{2} \mathrm{O}$. This benefit can be ascribed to the hydrolysis of isocyanate groups, which is an additional well-documented route for $\mathrm{NH}_{3}$ formation $[15,18,17]$. Although this process requires a catalytically active site $(S)$ to form the initial surface isocyanate species (Eqns. 5 and 7), the reaction steps responsible for the formation of $\mathrm{NH}_{3}$ can take place both in the gas phase (Eqn. 6) and via an adsorbed species on the catalyst surface (Eqn. 8);

$$
\begin{aligned}
& \mathrm{S}-\mathrm{NCO}+\mathrm{H}_{2} \mathrm{O} \rightarrow \mathrm{S}-\mathrm{OH}+\mathrm{HNCO} \\
& \mathrm{HNCO}+\mathrm{H}_{2} \mathrm{O} \rightarrow \mathrm{NH}_{3}+\mathrm{CO}_{2} \\
& \mathrm{~S}-\mathrm{NCO}+\mathrm{H}_{2} \mathrm{O} \rightarrow \mathrm{S}-\mathrm{NH}_{2}+\mathrm{CO}_{2} \\
& \mathrm{~S}-\mathrm{NH}_{2}+\mathrm{H}_{2} \mathrm{O} \rightarrow \mathrm{S}-\mathrm{OH}+\mathrm{NH}_{3}
\end{aligned}
$$

The objective of the present study is to investigate whether or not $\mathrm{NH}_{3}$ can be formed over a wide temperature window from $\mathrm{NO}+\mathrm{H}_{2}$ and $\mathrm{NO}+\mathrm{H}_{2} \mathrm{O}+\mathrm{CO}$ gas mixtures over supported Pt and Pd catalysts, specifically addressing the role of the support material. This is carried out by a systematic comparison of silica, alumina and titania as support materials. Also, the influence of the presence of $\mathrm{O}_{2}$ on the ammonia formation is studied. 


\section{Experimental section}

\subsection{Catalyst preparation and characterisation}

Supported Pt and Pd powder catalysts were prepared by incipient wetness impregnation of each of the following support materials: $\mathrm{Al}_{2} \mathrm{O}_{3}$ (Puralox SBa200), $\mathrm{SiO}_{2}$ (Kromasil) and $\mathrm{TiO}_{2}$ (Hombifine). The supports were thermally treated in air at 600 ${ }^{\circ} \mathrm{C}$ to remove impurities and stabilise the structure prior to impregnation. Thereafter, the saturation point of each support was determined and they were then suspended in the corresponding volume of aqueous solutions of either $\left(\mathrm{NH}_{3}\right)_{4} \mathrm{Pt}\left(\mathrm{NO}_{3}\right)_{2}$ or $\left(\mathrm{NH}_{3}\right)_{4} \mathrm{Pd}\left(\mathrm{NO}_{3}\right)_{2}$ to ensure all solution would be taken up by the support. All prepared catalysts were frozen in liquid $\mathrm{N}_{2}$ and subsequently freeze-dried for approximately twelve hours to ensure complete sublimation of water. The powder samples were then calcined at $550{ }^{\circ} \mathrm{C}$ in air for one hour.

The powder catalysts were then coated onto cordierite monolith substrates. This was done by preparing solutions consisting of the powder catalyst, suitable binder materials based on support composition $\left(\mathrm{Al}_{2} \mathrm{O}_{3}\right.$; Disperal $\mathrm{P} 2, \mathrm{SiO}_{2}$; Colloidal $\mathrm{SiO}_{2}$ and $\mathrm{TiO}_{2} ; \mathrm{TiO}_{2}$ sol), water and ethanol. The monolith was then carefully immersed into the slurry, allowing the catalystcontaining liquid to be dispersed evenly throughout the channels by capillary forces. The monolith was then dried in air at $90{ }^{\circ} \mathrm{C}$ for two minutes to remove the water and ethanol, before being briefly calcined in air for a further two minutes at 500 ${ }^{\circ} \mathrm{C}$ and weighed. If necessary, the process was repeated until the desired mass of catalyst and binder was deposited (200 \pm 3 $\mathrm{mg}$ ). Once coated, the monoliths were calcined in air at $600{ }^{\circ} \mathrm{C}$ for two hours to ensure complete removal of water.

The specific surface area of the prepared samples was measured by nitrogen physisorption at $-196^{\circ} \mathrm{C}$ using an ASAP 2010 (Micrometrics) sorptometer. Prior to adsorption, all samples were dried at $200{ }^{\circ} \mathrm{C}$ for two hours under vacuum in order to remove any residual water. Respective surface areas were then determined according to the standard Brunauer-Emmet-Teller (BET) method [19] using $P / P_{0}=0.05-0.20$. The specific surface area of the pure support materials; both fresh and after calcination in air at $600{ }^{\circ} \mathrm{C}$ for one hour was measured to determine the thermal stability of the supports. The prepared powder catalysts were characterised directly after calcination.

Transmission electron microscopy (TEM) analysis was carried out to determine the average noble metal particle size for each catalyst. A small amount of sample was dispersed in ethanol in an ultrasonic bath for 20 seconds. One drop of the suspension was then placed onto a $\mathrm{Cu}$-grid coated with lacey carbon. Between 6 - 14 images of each sample were recorded at different magnifications: 36 × 36 - 294 x 294 nm. Additionally, Energy dispersive spectroscopy (EDS) analyses were acquired at each position investigated to locate and confirm the presence and type of metal particles.

Inductively coupled plasma optical emission spectroscopy (ICP - OES) analysis was used to confirm the noble metal content of all samples. A mass of $0.1-0.15 \mathrm{~g}$ of finely ground sample was digested in a solution containing $\mathrm{HNO}_{3}$ and $\mathrm{HCl}$ at $200{ }^{\circ} \mathrm{C}$ for 20 minutes in a Milestone Ethos Plus microwave digestion unit. The resultant clear sample solution was then diluted using pure water (18.2 $\mathrm{M} \Omega)$ and the metal content was quantified with an Agilent 720 ES ICP - OES instrument. Emission signals from the sample were compared to the signal from certified calibration standards containing 0 - $10 \mathrm{mg} / \mathrm{l} \mathrm{Pd}$ or Pt.

To compliment the afore-mentioned characterisation techniques, powder X-ray diffraction (XRD) was also performed using a Bruker XRD D8 Advance instrument with monochromatic $\mathrm{CuK} \alpha_{1}$ radiation. The $2 \theta$ range of interest was $15-85^{\circ}$ and the step size and time employed were 0.041 and $1 \mathrm{~s}$, respectively. The rotation speed of the sample during measurement was $60 \mathrm{rpm}$. 
Table 1: Summary of gas compositions used in the temperature programmed reaction experiments.

\begin{tabular}{lcccc}
\hline \hline & $\mathrm{NO}[\mathrm{ppm}]$ & $\mathrm{H}_{2}[\mathrm{ppm}]$ & $\mathrm{CO}[\mathrm{ppm}]$ & $\mathrm{H}_{2} \mathrm{O}[\%]$ \\
\hline Feed 1 & 500 & 1500 & - & - \\
Feed 2 & 500 & - & 1500 & 2 \\
Feed 3 & - & - & 1500 & 2 \\
\hline
\end{tabular}

\subsection{Kinetic measurements in gas flow reactor}

Continuous gas flow reactor studies were carried out to determine the activity of the prepared catalysts. The reactor setup employed in this investigation has previously been described by Kannisto et al. [20]. The system consists of a quartz tube surrounded with a heating coil and insulation. It contains two thermocouples to measure the temperature both $10 \mathrm{~mm}$ before and in the centre of the monolith sample. Two uncoated (blank) cordierite monoliths were placed on either side of the sample monolith in the quartz tube in order to reduce otherwise significant heat losses and achieve a nearly isothermal sample. The inlet gas composition was controlled using mass flow controllers (Bronkhorst Hi-Tech LOW-AP-FLOW) and the outlet gas composition was analysed using an FTIR gas-analyzer (MKS 2030 HS). All experiments were carried out with an Ar balance in order to keep the total gas flow constant at $2000 \mathrm{ml} / \mathrm{min}$, corresponding to a space velocity of $40000 \mathrm{~h}^{-1}$.

Temperature programmed reaction experiments were carried out to investigate the temperature region for ammonia formation over the different samples. All samples were exposed to gas mixtures containing 500 ppm NO and either 1500 ppm $\mathrm{H}_{2}$ (Feed 1) or 1500 ppm CO accompanied by $2 \% \mathrm{H}_{2} \mathrm{O}$ (Feed 2), see Table 1. During exposure to both gas mixtures, the inlet temperature was varied from 500 to $120^{\circ} \mathrm{C}$ at a rate of 6 ${ }^{\circ} \mathrm{C} / \mathrm{min}$. The system was then kept at this temperature for ten minutes before increasing the temperature to $500{ }^{\circ} \mathrm{C}$ at the same rate. The low ramp rate was chosen as to ensure nearly stationary conditions. This scheme was carried out both in the absence and presence of $2 \% \mathrm{O}_{2}$. An additional experiment was carried out in order to determine the activity for the water-gas-shift reaction of the samples, represented by Feed 3 in Table 1.

Steady-state experiments at 250,350 and $450{ }^{\circ} \mathrm{C}$ were carried out to evaluate the influence of the stoichiometric number, S, of the feed on the formation of $\mathrm{NH}_{3}$ over the catalysts. The Svalue characterizes the net oxidizing-reducing character of the inlet feed and is defined as [21];

$$
\mathrm{S}=\frac{2\left[\mathrm{O}_{2}\right]+[\mathrm{NO}]}{[\mathrm{CO}]+\left[\mathrm{H}_{2}\right]}
$$

Again, the two feed compositions were fed to the reactor though this time various levels of oxygen were also added. The $\mathrm{O}_{2}$ concentration was varied from 0.105 to $0.015 \%$ (corresponding to S-values between 1.73 and 0.33 ) in steps of $150 \mathrm{ppm}$, each of which lasted 20 minutes in order to allow steady state to be reached.

\subsection{In situ infrared Fourier transform spectroscopy}

Infrared Fourier transform spectroscopy was carried out in situ in diffuse reflection mode (DRIFTS) to follow the evolution of surface species during $\mathrm{NH}_{3}$ formation. A Biorad FTS6000 spectrometer equipped with an in situ Harrick Praying Mantis reaction cell mounted with $\mathrm{KBr}$ windows was used. All samples were pretreated in an Ar flow at $450{ }^{\circ} \mathrm{C}$ for 30 minutes, cooled to $350{ }^{\circ} \mathrm{C}$ and a background spectrum was collected. The feed gas was then 500 ppm NO, 1500 ppm $\mathrm{CO}$ and $2 \% \mathrm{H}_{2} \mathrm{O}$ with varying concentration of $\mathrm{O}_{2}$ ranging from 900 to 0 ppm (corresponding to S-values between 1.53 and 0.33 ) in steps of 150 ppm. Infrared spectra were recorded between 1200 and 3800 $\mathrm{cm}^{-1}$ after the catalyst had been exposed to each gas composition for 20 minutes. The spectra displayed in the figures are difference spectra, i.e., the spectra obtained after background subtraction, in order to more clearly show the adsorbates as a function of the gas phase composition. 
Table 2: BET, ICP-OES and TEM characterization of prepared samples.

\begin{tabular}{lccc}
\hline \hline Sample & $\begin{array}{c}\text { Surface } \\
\text { area } \\
{\left[\mathrm{m}^{2} / \mathrm{g}\right]}\end{array}$ & $\begin{array}{c}\text { Metal } \\
\text { content } \\
\text { [wt. \%] }\end{array}$ & $\begin{array}{c}\text { Noble metal } \\
\text { particle size } \\
\text { range [nm] }\end{array}$ \\
\hline Fresh $\mathrm{TiO}_{2}$ & 337 & - & - \\
$\mathrm{Calcined}^{a} \mathrm{TiO}_{2}$ & 42 & - & - \\
$\mathrm{Pd} / \mathrm{TiO}_{2}$ & 41 & 0.37 & $b$ \\
$\mathrm{Pt} / \mathrm{TiO}_{2}$ & 39 & 0.97 & $b$ \\
\hline${\text { Fresh } \mathrm{SiO}_{2}}_{\mathrm{Calcined}} \mathrm{SiO}_{2}$ & 322 & - & - \\
$\mathrm{Pd} / \mathrm{SiO}_{2}$ & 326 & - & - \\
$\mathrm{Pt} / \mathrm{SiO}_{2}$ & 329 & 0.47 & $1.5-7$ \\
\hline $\mathrm{Fresh} \mathrm{Al}_{2} \mathrm{O}_{3}$ & 320 & 0.99 & $1-120$ \\
$\mathrm{Calcined}{ }^{a} \mathrm{Al}_{2} \mathrm{O}_{3}$ & 200 & - & - \\
$\mathrm{Pd} / \mathrm{Al}_{2} \mathrm{O}_{3}$ & 201 & - & - \\
$\mathrm{Pt} / \mathrm{Al}_{2} \mathrm{O}_{3}$ & 192 & 0.49 & $b$ \\
\hline $\mathrm{Afftr}$ & 188 & 0.93 & $2-21$ \\
\hline
\end{tabular}

${ }^{a}$ After calcination in air at $600{ }^{\circ} \mathrm{C}$ for one hour.

${ }^{b}$ Samples in which the location of metal particles is unclear.

\section{Results}

\subsection{Catalyst characterization}

The catalysts prepared were characterised with respect to specific surface area, noble metal content and noble metal particle size. These results, together with the results for the specific surface area measurements of the pure support materials are summarised in Table 2. It can be seen that the surface area of the $\mathrm{Al}_{2} \mathrm{O}_{3}$ and $\mathrm{SiO}_{2}$ supported catalysts remain relatively unchanged after both thermal treatment and noble metal impregnation. However, a large loss in surface area can be observed for the $\mathrm{TiO}_{2}$ support when calcined at $600{ }^{\circ} \mathrm{C}$. The metal content of all Pt containing catalysts was confirmed by ICP-OES analysis to be 1 wt. $\% \pm 0.07$ and that of the $\mathrm{Pd}$ series to be 0.5 wt. $\% \pm 0.13$.

In Figure 1, the results from the XRD and TEM analysis of all samples are shown. The X-ray diffractograms of the pure support materials are also displayed as a reference in order to determine whether impregnation of the noble metal results in well-dispersed or larger particles. The diffractogram for the fresh $\mathrm{TiO}_{2}$ support is also included in the analysis as a phase-change from anatase to rutile is suspected to be the explanation for the large decrease in surface area as a result of thermal treatment, as revealed by the BET analysis. However, XRD confirms that $\mathrm{TiO}_{2}$ remains present in the form of anatase but the primary particles of the porous titania support have grown considerably after calcination at $600{ }^{\circ} \mathrm{C}$. This can be concluded from the substantial increase in intensity of the diffraction peaks. In the case of the Pd impregnated samples, there appears to be no difference between the diffractograms of the impregnated sample and respective support material. This indicates that the Pd particles are either very small and well dispersed or too amorphous to be detected by XRD. However, a combination of both of these effects could also explain the absence of diffraction peaks related to $\mathrm{Pd}$ and should not be ruled out. X-ray diffraction peaks from metallic Pt (111) are detected for all supports impregnated with Pt and can be seen at $2 \theta=40^{\circ}$ (indicated in the diffractograms by the dashed line) [22]. The metal particle size range is determined using TEM imaging. The silica supported noble metal particles are easily detected during the analysis due to good contrast between the noble metal and the support. A relatively narrow range of small particles was observed for the Pd sample $(1.5$ - $7 \mathrm{~nm})$ whereas a much wider range is observed for the silica support impregnated with Pt (1 - $120 \mathrm{~nm})$. It was also possible to measure noble metal particle size for the $\mathrm{Pt} / \mathrm{Al}_{2} \mathrm{O}_{3}$ sample. Comparing $\mathrm{Pt} / \mathrm{SiO}_{2}$ with $\mathrm{Pt} / \mathrm{Al}_{2} \mathrm{O}_{3}$, we see a much broader range in size of noble metal particles on the $\mathrm{SiO}_{2}$ supported sample than that of the $\mathrm{Al}_{2} \mathrm{O}_{3}$ supported sample $(2-21 \mathrm{~nm})$. From the TEM micrographs for $\mathrm{Pd} / \mathrm{TiO}_{2}, \mathrm{Pt} / \mathrm{TiO}_{2}$ and $\mathrm{Pd} / \mathrm{Al}_{2} \mathrm{O}_{3}$, it is difficult to distinguish individual metal particles (represented in the table by ${ }^{b}$ ). In the case of $\mathrm{Al}_{2} \mathrm{O}_{3}$ and $\mathrm{TiO}_{2}$ supported $\mathrm{Pd}$, although the particles could not be distinguished well enough to determine their size, their presence was confirmed by EDS.

\subsection{Kinetic measurements in gas flow reactor}

Figure 2 shows the formation of $\mathrm{NH}_{3}$ over the catalysts in the presence of $\mathrm{NO}$ and $\mathrm{H}_{2}$ (Feed 1) as a function of the in- 

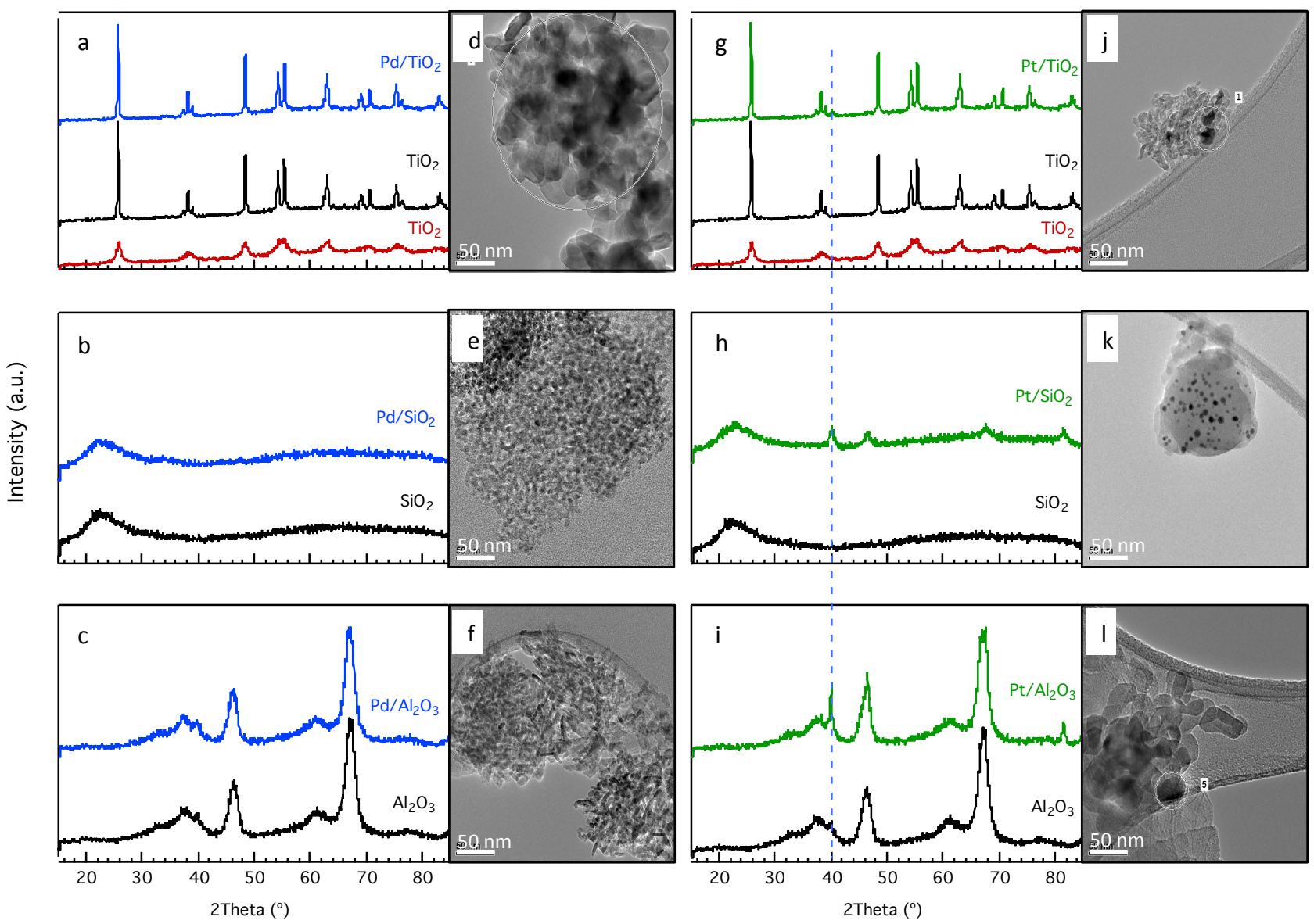

Figure 1: XRD diffractograms of a) $\mathrm{Pd} / \mathrm{TiO}_{2}$, b) $\mathrm{Pd} / \mathrm{SiO}_{2}$, c) $\mathrm{Pd} / \mathrm{Al}_{2} \mathrm{O}_{3}, \mathrm{~g}$ ) $\left.\mathrm{Pt} / \mathrm{TiO}_{2}, \mathrm{~h}\right) \mathrm{Pt} / \mathrm{SiO}_{2}$ and i) $\mathrm{Pt} / \mathrm{Al}_{2} \mathrm{O}_{3}$. Diffractograms of the pure supports are also included for reference. TEM images of d) $\mathrm{Pd} / \mathrm{TiO}_{2}$, e) $\left.\mathrm{Pd} / \mathrm{SiO}_{2}, \mathrm{f}\right) \mathrm{Pd} / \mathrm{Al}_{2} \mathrm{O}_{3}, \mathrm{j}$ ) $\mathrm{Pt} / \mathrm{TiO}_{2}, \mathrm{k}$ ) $\mathrm{Pt} / \mathrm{SiO}_{2}$ and l) $\mathrm{Pt} / \mathrm{Al}_{2} \mathrm{O}_{3}$. The dashed line indicates the position of diffraction from $\mathrm{Pt}(111)$. The scale bars measure 50nm.

let gas temperature. The inlet concentration of $\mathrm{NO}$ is $500 \mathrm{ppm}$, thus the maximum concentration of $\mathrm{NH}_{3}$ that can be achieved at steady-state is $500 \mathrm{ppm}$. It can thus be seen that near complete conversion of $\mathrm{NO}$ to $\mathrm{NH}_{3}$ takes place over the $\mathrm{SiO}_{2}$ and $\mathrm{Al}_{2} \mathrm{O}_{3}$ supported catalysts between 300 and $425^{\circ} \mathrm{C}$. Below $200{ }^{\circ} \mathrm{C}$, the catalysts containing $\mathrm{Pt}$ show higher activity for $\mathrm{NH}_{3}$ formation than their Pd containing counterparts. When exposed to this low-temperature interval, the formation of $\mathrm{N}_{2} \mathrm{O}$ and $\mathrm{N}_{2}$ are also observed in small quantities over all samples, as well as a small decrease in NO conversion (ca. $10 \%$ ). At high temperature, $>400{ }^{\circ} \mathrm{C}$, the type of support appears to have the dominating effect on the formation of $\mathrm{NH}_{3}$. Neither of the $\mathrm{TiO}_{2}$ supported catalysts achieve considerable conversion of $\mathrm{NO}$ to $\mathrm{NH}_{3}$ when compared to the corresponding $\mathrm{SiO}_{2}$ and $\mathrm{Al}_{2} \mathrm{O}_{3}$ supported samples. The maximum conversion to $\mathrm{NH}_{3}$ observed over the titania supported samples is around 50 and $60 \%$ for the $\mathrm{Pd}$ and $\mathrm{Pt}$ containing catalysts, respectively. When repeated in the presence of excess $\mathrm{O}_{2}$, the formation of $\mathrm{N}_{2} \mathrm{O}$ and $\mathrm{NO}_{2}$ is detected although the majority of NO remained unreacted. In general, more $\mathrm{NO}_{2}$ is formed over Pt-containing samples over a broader temperature range, with a maximum of ca. $150 \mathrm{ppm}$ observed over $\mathrm{Pt} / \mathrm{SiO}_{2}$ centered at a temperature of $300{ }^{\circ} \mathrm{C}$, compared to ca. $50 \mathrm{ppm}$ formed over $\mathrm{Pd} / \mathrm{SiO}_{2}$ at $420{ }^{\circ} \mathrm{C}$. Small amounts of $\mathrm{N}_{2} \mathrm{O}$ are again observed at temperatures below $200{ }^{\circ} \mathrm{C}$. The Pt-containing samples were again found to be more active for the formation of this undesirable product, with an average pro- 


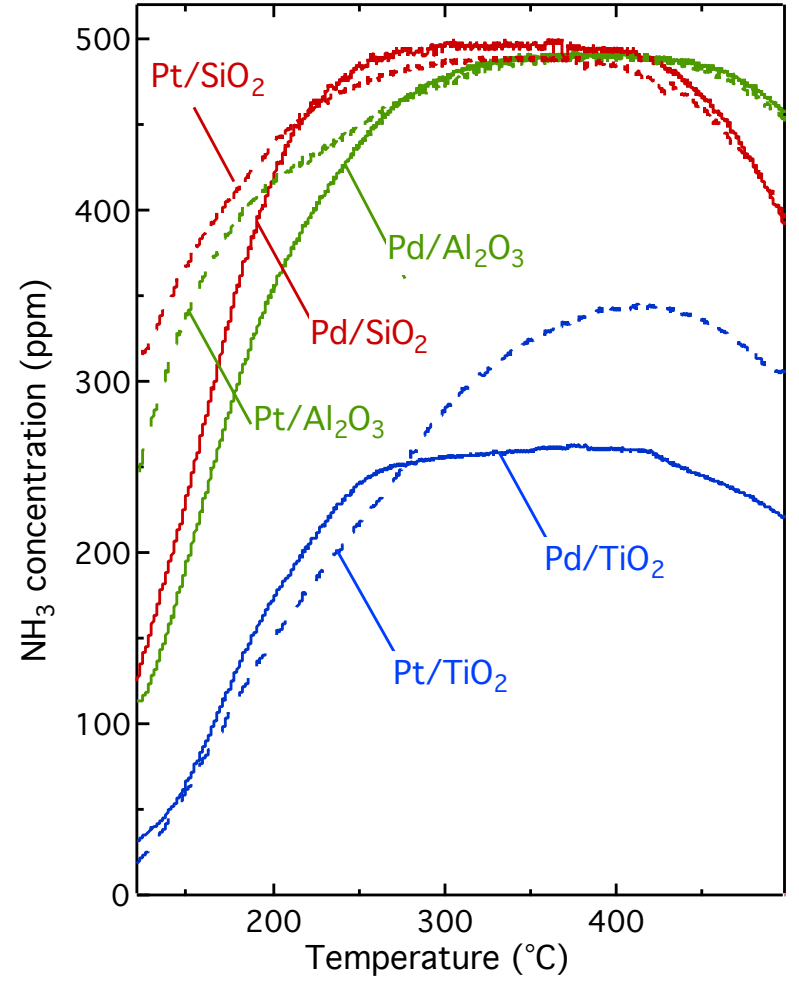

Figure 2: Ammonia formation over silica, alumina and titania supported Pt and $\mathrm{Pd}$ catalysts during temperature programmed reaction using $500 \mathrm{ppm} \mathrm{NO}$ and $1500 \mathrm{ppm} \mathrm{H}_{2}$ in $\mathrm{Ar}$ in the gas feed and a temperature ramp rate of $6{ }^{\circ} \mathrm{C} / \mathrm{min}$. The space velocity was $40000 \mathrm{~h}^{-1}$.

duction of 100 ppm $\mathrm{N}_{2} \mathrm{O}$ compared to ca. 20 ppm over Pdcontaining products.

Figure $3 \mathrm{a}$ and $\mathrm{b}$ show the formation of $\mathrm{NH}_{3}$ and $\mathrm{CO}_{2}$ in the presence of $\mathrm{NO}, \mathrm{CO}$ and $\mathrm{H}_{2} \mathrm{O}$ (Feed 2) as a function of inlet gas temperature for all catalysts whilst Figure $3 \mathrm{c}$ shows the corresponding $\mathrm{CO}_{2}$ production in the presence of $\mathrm{CO}$ and $\mathrm{H}_{2} \mathrm{O}$ only (Feed 3). At temperatures below $275^{\circ} \mathrm{C}$, the formation of $\mathrm{H}_{2}$ is higher over all Pd containing samples as compared to those catalysts that contain Pt. However, this trend reverses above this temperature when, with the exception of $\mathrm{Pd} / \mathrm{Al}_{2} \mathrm{O}_{3}$, the hydrogen formation over the Pt containing samples is higher than over the corresponding Pd catalysts. This corresponds well with the results in Figure 3a which show that the formation of $\mathrm{NH}_{3}$ generally is higher over the $\mathrm{Pd}$ samples below $275^{\circ} \mathrm{C}$ and over the Pt samples when this temperature is exceeded. However, this effect cannot only be explained by the WGS activity of the
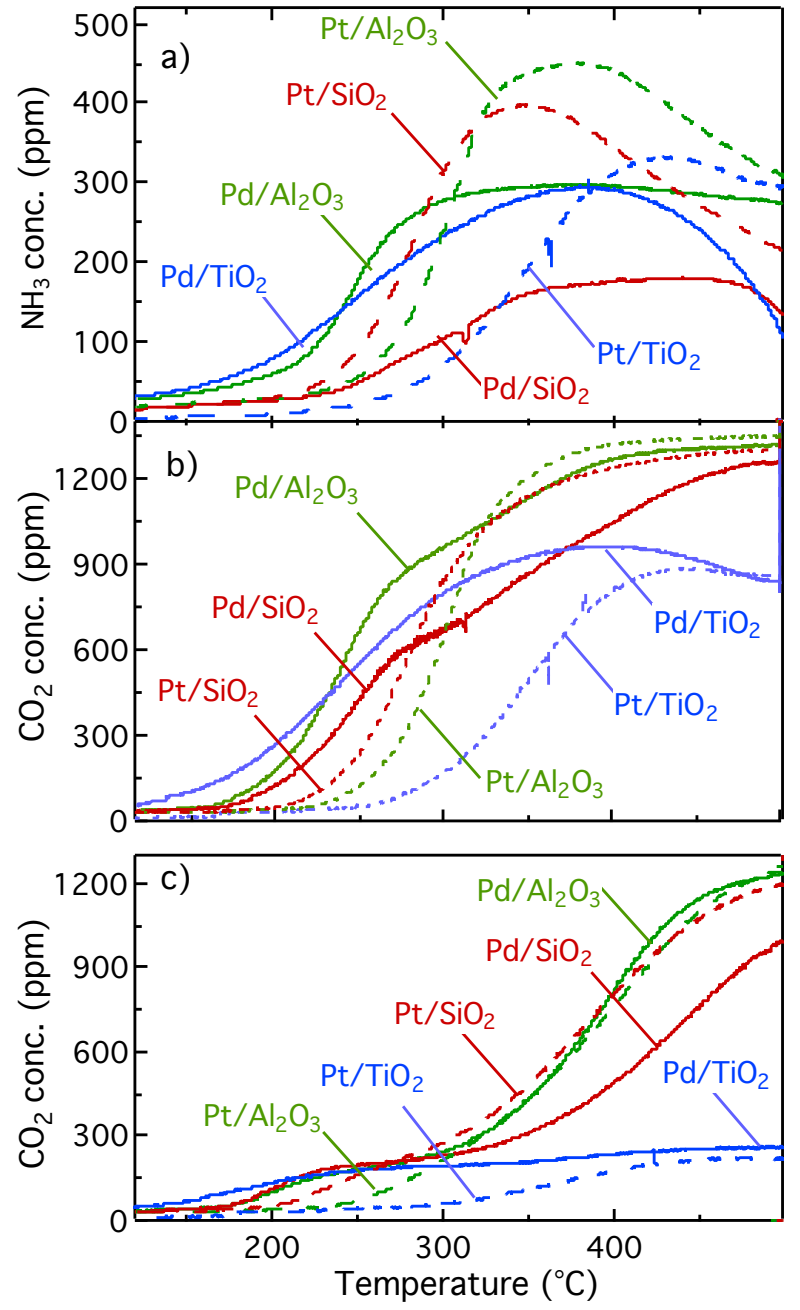

Figure 3: Temperature programmed reaction experiments; formation of a) ammonia b) carbon dioxide during WGS-assisted formation of $\mathrm{NH}_{3}$ using 500 ppm NO, 1500 ppm CO and $2 \% \mathrm{H}_{2} \mathrm{O}$ in $\mathrm{Ar}$ in the gas feed. Panel c) shows the formation of carbon dioxide during WGS conditions feeding $1500 \mathrm{ppm} \mathrm{CO}$ and $2 \% \mathrm{H}_{2} \mathrm{O}$ in Ar. In all experiments a space velocity of $40000 \mathrm{~h}^{-1}$ was used

catalysts, since more $\mathrm{NH}_{3}$ is seen to be formed between 200 and $400{ }^{\circ} \mathrm{C}$ in Figure $3 \mathrm{a}$ than $\mathrm{H}_{2}$ is formed in Figure $3 \mathrm{c}$ during the pure WGS reaction (absence of NO). In fact, the increased $\mathrm{CO}_{2}$ formation observed in $3 \mathrm{~b}$ may explain this behaviour and is discussed further in the final section. Unlike in the previous experiment with $\mathrm{H}_{2}$ and $\mathrm{NO}$ (Feed 1), the $\mathrm{Al}_{2} \mathrm{O}_{3}$ supported catalysts are now found to be more active than their $\mathrm{SiO}_{2}$ supported counterparts. Interestingly, during the WGS-assisted experiments, the $\mathrm{TiO}_{2}$ supported catalysts do not appear as inferior for $\mathrm{NH}_{3}$ formation as they do when $\mathrm{H}_{2}$ is available directly in the feed gas. In fact, both samples are able to form higher amounts of 
$\mathrm{NH}_{3}$ than the $\mathrm{Pd} / \mathrm{SiO}_{2}$ catalyst. With regards to $\mathrm{N}_{2} \mathrm{O}$, it is observed that this product is now formed over a much broader temperature range $\left(200-400{ }^{\circ} \mathrm{C}\right)$ than when $\mathrm{H}_{2}$ was directly available in the gas feed. On average, $40 \mathrm{ppm} \mathrm{N}_{2} \mathrm{O}$ is produced over Pd-containing samples whilst around $10 \mathrm{ppm}$ is detected over their Pt-containing counterparts. Unlike the case when $\mathrm{H}_{2}$ is directly available in the gas feed, no $\mathrm{N}_{2}$ is formed in the lowtemperature interval when $\mathrm{CO}$ and $\mathrm{H}_{2} \mathrm{O}$ are used as reductants. However, $\mathrm{N}_{2}$ begins to form at temperatures exceeding about $350{ }^{\circ} \mathrm{C}$. When this experiment is repeated in the presence of excess $\mathrm{O}_{2}, \mathrm{NO}_{2}$ is formed in very similar amounts to those described for the same reaction with $\mathrm{H}_{2}$ directly available in the gas mixture. As before, the most of the NO remains unreacted in the presence of excess $\mathrm{O}_{2}$. However, no $\mathrm{N}_{2} \mathrm{O}$ is formed over any sample when using $\mathrm{CO}$ and $\mathrm{H}_{2} \mathrm{O}$ as reductants.

Figure 4 shows the steady-state formation of $\mathrm{NH}_{3}$ from $\mathrm{NO}$ and $\mathrm{H}_{2}$ over the catalysts as a function of the stoichiometric number of the feed at 250,350 and $450{ }^{\circ} \mathrm{C}$. The stoichiometric number is varied by varying the oxygen concentration of the feed, where $S<1$ represents a net-reducing feed and $S>1$ is net-oxidizing. When the concentration of oxygen fed to the reactor is $500 \mathrm{ppm}$ the feed is stoichiometrically balanced and the $\mathrm{S}$-value is 1.0. For all samples, it can be seen that the $\mathrm{NH}_{3}$ formation starts when the S-value is lower than 1.0 and increases significantly upon decreasing S-value. With the exception of $\mathrm{Pt} / \mathrm{TiO}_{2}$, altering of the inlet gas temperature has negligible effect on the $\mathrm{NH}_{3}$ formation over the samples when hydrogen is included in the feed gas.

The corresponding experiments for the influence of the Svalue on the WGS-assisted $\mathrm{NH}_{3}$ formation are displayed in Figure 5. Again we see that the formation of $\mathrm{NH}_{3}$ starts when the feed becomes net-reducing and increases significantly with decreasing S-value. However, in contrast to the corresponding experiment with $\mathrm{H}_{2}$ and $\mathrm{NO}$, the ammonia formation from the

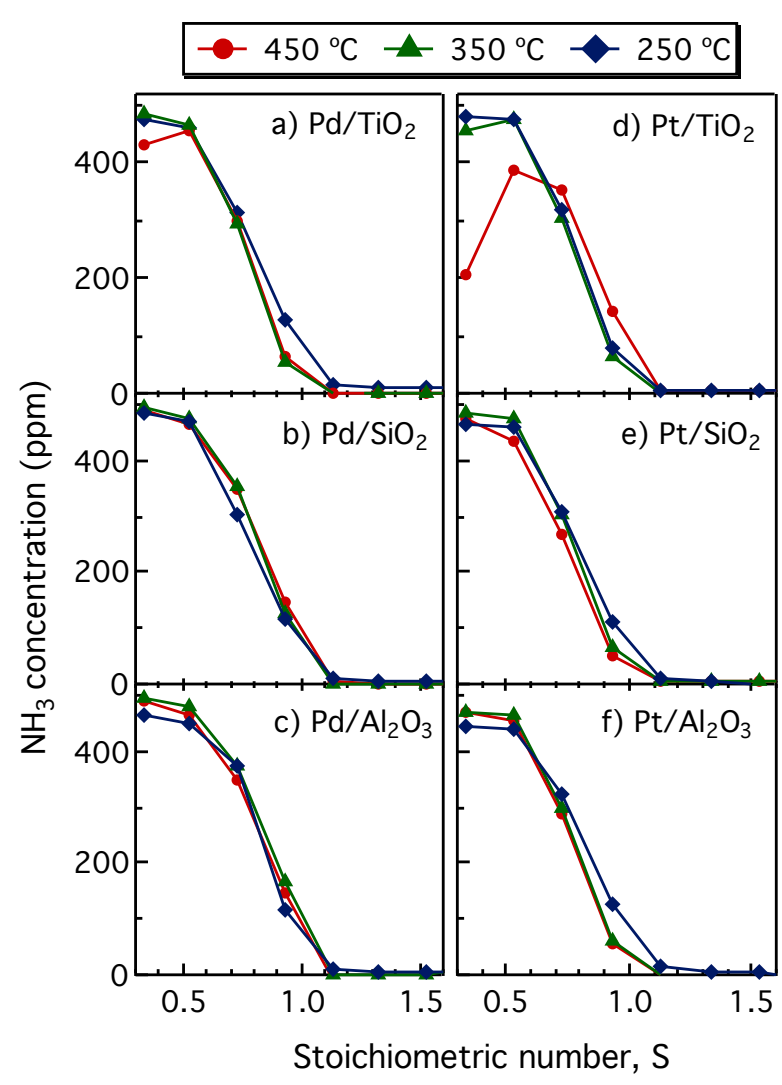

Figure 4: Steady-state formation of $\mathrm{NH}_{3}$ versus oxygen concentration at 250, 350 and $450{ }^{\circ} \mathrm{C}$. The gas feed contained $500 \mathrm{ppm} \mathrm{NO}$ and $1500 \mathrm{ppm} \mathrm{H}_{2}$ while the $\mathrm{O}_{2}$ concentration was varied between 0 and $1050 \mathrm{ppm}(\mathrm{S}=0.33-1.73)$ in steps of $150 \mathrm{ppm}$. Ar was used as balance and space velocity was $40000 \mathrm{~h}^{-1}$.

feed with $\mathrm{H}_{2} \mathrm{O}$, $\mathrm{CO}$ and $\mathrm{NO}$ is clearly dependent on the temperature. At $250{ }^{\circ} \mathrm{C}, \mathrm{NH}_{3}$ is exclusively formed over those catalysts which contain Pd with the exception of silica supported Pd. However, at higher temperatures, the $\mathrm{NH}_{3}$ formation increases over the Pt containing catalysts. These results further correlate with the $\mathrm{H}_{2}$ formation trends observed in Figure $2 \mathrm{~b}$ where it can be seen that the Pd samples are more active at low temperatures whereas the Pt samples are more active at higher temperatures. An interesting observation during both the hydrogen and the WGS oxygen dependence reactions over $\mathrm{Pt} / \mathrm{TiO}_{2}$ at elevated temperatures $\left(350\right.$ and $\left.450{ }^{\circ} \mathrm{C}\right)$, is that the presence of $150 \mathrm{ppm} \mathrm{O}_{2}(\mathrm{~S}=0.53)$ results in higher $\mathrm{NH}_{3}$ formation than complete absence of $\mathrm{O}_{2}$ in the feed. 


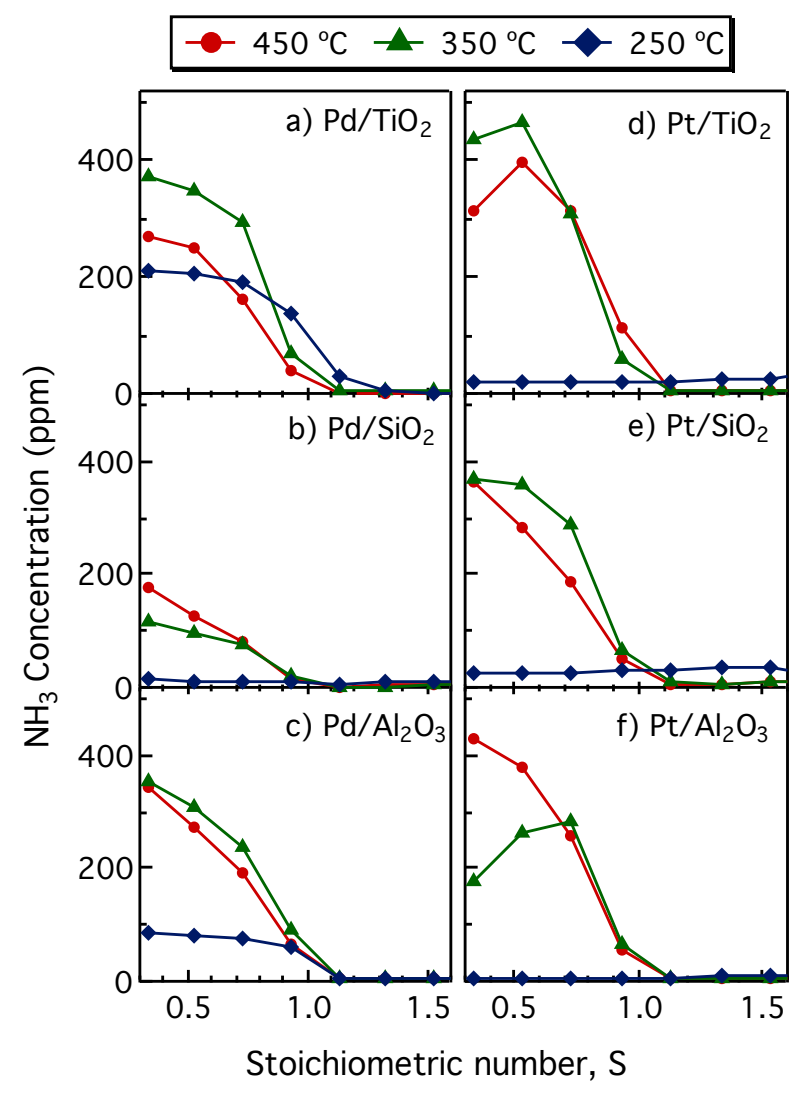

Figure 5: Steady-state WGS assisted formation of $\mathrm{NH}_{3}$ versus oxygen concentration at 250,350 and $450{ }^{\circ} \mathrm{C}$. The gas feed contained $500 \mathrm{ppm}$ NO, $1500 \mathrm{ppm}$ $\mathrm{CO}$ and $2 \% \mathrm{H}_{2} \mathrm{O}$ while the $\mathrm{O}_{2}$ concentration was varied between 0 and 1050 $\mathrm{ppm}(\mathrm{S}=0.33-1.73)$ in steps of $150 \mathrm{ppm}$. Ar was used as balance and space velocity was $40000 \mathrm{~h}^{-1}$.

\subsection{In situ DRIFT spectroscopy}

The results from the in situ DRIFT spectroscopy experiments for the alumina and titania supported platinum samples during WGS-assisted ammonia formation conditions as a function of the S-value are shown in Figure 6. The corresponding results for the alumina and titania supported Pd samples are shown in Figure 7. The stoichiometric number of the feed employed during each step is displayed on each spectrum and those experiments carried out under net-oxidizing conditions are represented by blue spectra, whereas those performed in the presence of net-reducing feeds are represented by green spectra. All peak assignments made are summarised together with references to previous studies in Table 3.

In the presence of excess $\mathrm{O}_{2}(\mathrm{~S}>1)$ a significant absorp-

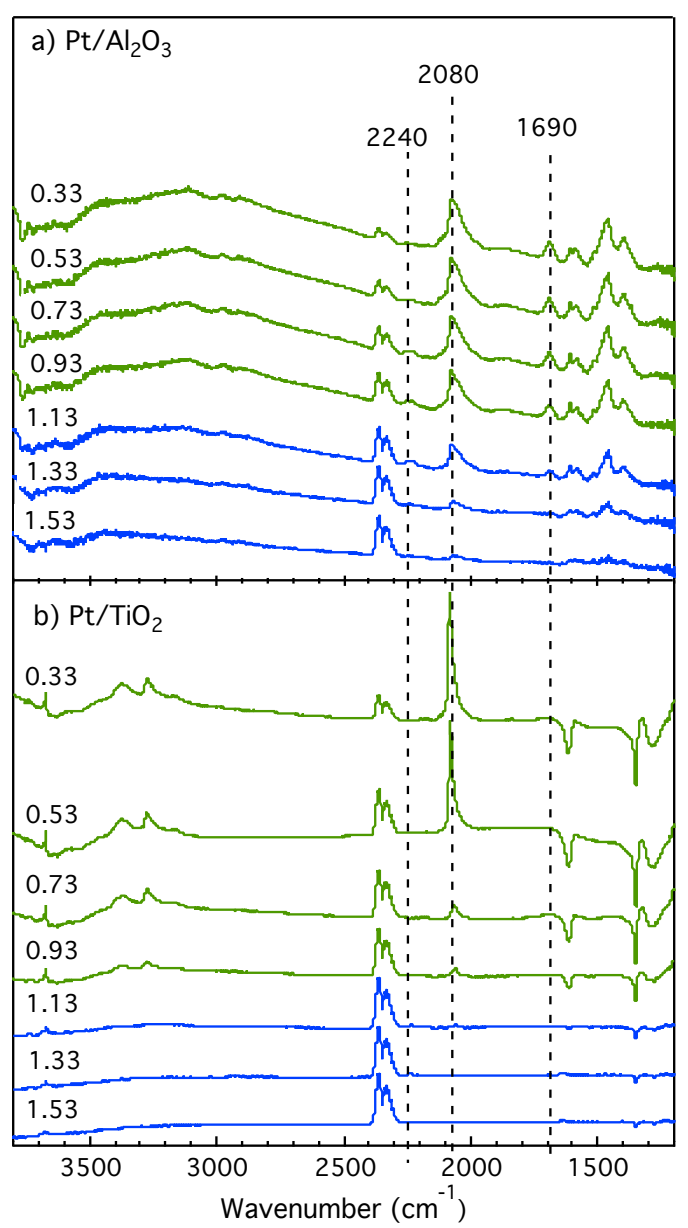

Figure 6: DRIFT spectra acquired on a) $\mathrm{Pt} / \mathrm{Al}_{2} \mathrm{O}_{3}$ and b) $\mathrm{Pt} / \mathrm{TiO}_{2}$ at constant temperature $\left(350^{\circ} \mathrm{C}\right)$ with inlet concentration of $500 \mathrm{ppm} \mathrm{NO}, 1500 \mathrm{ppm} \mathrm{CO}$ and $2 \% \mathrm{H}_{2} \mathrm{O} . \mathrm{O}_{2}$ concentration was varied between 0 and $1050 \mathrm{ppm}(\mathrm{S}=0.33$ 1.53 ) and is represented by the stoichiometric value of the gas feed. Ar balance was employed during all steps.

tion band representing gaseous $\mathrm{CO}_{2}\left(2350-2360 \mathrm{~cm}^{-1}\right)$ can be observed for all samples. As the $\mathrm{O}_{2}$ concentration is lowered, the contribution of this band decreases significantly. This is accompanied by an increased band intensity for both bridgebonded $\left(1936 \mathrm{~cm}^{-1}\right)$ and linearly adsorbed (2050 - 2070 and $2080 \mathrm{~cm}^{-1}$ ) CO on Pt and Pd as well as an observed increase in the intensity of the NH stretching vibrations in the 3150 - 3400 $\mathrm{cm}^{-1}$ region, corresponding to an increase in the amount of surface bound $\mathrm{NH}_{3}$. An increase in the intensity of bands due to the adsorption of $\mathrm{NH}_{2}$ is also observed at $1321 \mathrm{~cm}^{-1}$ for both $\mathrm{TiO}_{2}$ supported catalysts. For both $\mathrm{Al}_{2} \mathrm{O}_{3}$ supported catalysts, an absorption band representative of cyanate groups $\left(2240 \mathrm{~cm}^{-1}\right)$ can 


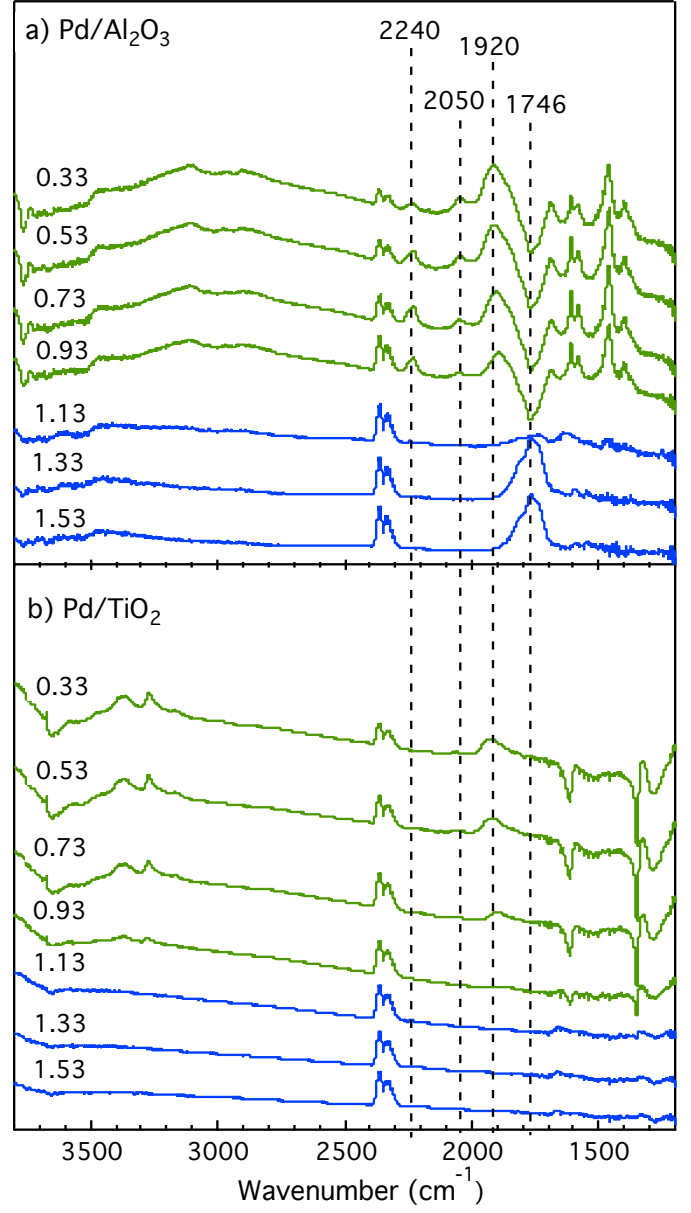

Figure 7: DRIFT specta aquired on a) $\mathrm{Pd} / \mathrm{Al}_{2} \mathrm{O}_{3}$ and b) $\mathrm{Pd} / \mathrm{TiO}_{2}$ at constant temperature $\left(350^{\circ} \mathrm{C}\right)$ with inlet concentration of $500 \mathrm{ppm} \mathrm{NO}, 1500 \mathrm{ppm} \mathrm{CO}$ and $2 \% \mathrm{H}_{2} \mathrm{O} . \mathrm{O}_{2}$ concentration was varied between 0 and $1050 \mathrm{ppm}(\mathrm{S}=0.33$ - 1.53) and Ar balance was employed

be seen once the feed becomes net-reducing. This band shows an initial increase when the S-value is decreased. However, after the S-value reaches 0.73 , the intensity of this band starts to decrease, having negligible contribution to the spectra obtained in the absence of oxygen. Again, this trend is accompanied by an increase in intensity of the absorption bands in the NH stretching region $\left(3150-3400 \mathrm{~cm}^{-1}\right)$ showing an increase in surface bound $\mathrm{NH}_{3}$. Also worth mentioning is the notable absence of peaks representative for noble metal coordinated NO (1668, 1746 and $\left.1828 \mathrm{~cm}^{-1}\right)$ and support bound nitrates (1440, 1460,1590 and $1610 \mathrm{~cm}^{-1}$ ) in the presence of excess oxygen for the $\mathrm{Al}_{2} \mathrm{O}_{3}$ supported samples. However, all these bands increase significantly and simultaneously as the feed becomes net-reducing.

For the $\mathrm{Pd} / \mathrm{Al}_{2} \mathrm{O}_{3}$ sample, in the presence of excess $\mathrm{O}_{2}$, an intense absorption peak ascribed to linearly adsorbed $\mathrm{NO}$ on $\mathrm{Pd}^{0}$ $\left(1746 \mathrm{~cm}^{-1}\right)$ can be observed. However, upon reducing the Svalue of the feed below 1.0, this peak rapidly levels out before becoming negative. The evolution of the negative peak is accompanied by the detection of a small shoulder peak representative of linearly adsorbed $\mathrm{NO}$ on $\mathrm{Pd}^{+}\left(1828 \mathrm{~cm}^{-1}\right)$, indicating the presence of two different Pd adsorption sites.

For the two titania supported samples, fewer and less intense absorption bands are observed during the in situ DRIFT experiments. For both samples, there is also a notable contribution of a sharp negative peak at $1610 \mathrm{~cm}^{-1}$. Since the samples are pretreated with $\mathrm{O}_{2}$ before a background spectrum is taken, it is assumed that the $\mathrm{Pd}$ and $\mathrm{TiO}_{2}$ particles are in an oxidized state. Bickmore et al. have previously assigned an absorption band at $1610 \mathrm{~cm}^{-1}$ to physisorbed H-bonded water [23]. Furthermore, Benesi et al. observed an absorption peak at $1610 \mathrm{~cm}^{-1}$ after exposing silica to $\mathrm{H}_{2} \mathrm{O}$ [24]. However, upon injection of $\mathrm{D}_{2} \mathrm{O}$ in place of $\mathrm{H}_{2} \mathrm{O}$, the authors found that the position of this peak remained unchanged. As a result, the authors suggested that this band is due to surface silanol groups. In our case, it may not be unreasonable to suggest that we too observe surface hydroxyl groups at this position. It has previously been reported that $\mathrm{OH}$ groups on $\mathrm{TiO}_{2}$ can readily combine to form Ti-O-Ti [25]. Thus, the increase in intensity of these negative peaks as the feed becomes increasingly net-reducing is suspected to be related to the reduction of surface hydroxyl groups on the titania supported sample. Hence the negative peaks observed in the DRIFTS-spectra.

\section{Discussion}

We have shown that by using $\mathrm{NO}$ and $\mathrm{H}_{2}$, either direct or formed from water and $\mathrm{CO}$ via the water-gas-shift reaction, 
Table 3: Summary of vibration and species assignments for the in situ DRIFTS experiments. (s) and (as) represent the symmetric and asymmetric stretching vibrations respectively.

\begin{tabular}{cccc}
\hline \hline Wavenumber $\left(\mathrm{cm}^{-1}\right)$ & Vibration & Species & Ref. \\
\hline 1321 & $\mathrm{H}-\mathrm{N}-\mathrm{H}(\mathrm{as})$ & $\mathrm{NH}_{2}$ on $\mathrm{TiO}_{2}$ & {$[26]$} \\
1440 & $\mathrm{CO}_{2}(\mathrm{as})$ & Bicarbonate on $\mathrm{Al}_{2} \mathrm{O}_{3}$ & {$[27,28]$} \\
1460 & $\mathrm{~N}=\mathrm{O}(\mathrm{s})$ & Linearly bound nitrate on $\mathrm{Al}_{2} \mathrm{O}_{3}$ & {$[28]$} \\
1590 & $\mathrm{~N}=\mathrm{O}(\mathrm{s})$ & Chelating bidentate nitrate on $\mathrm{Al}_{2} \mathrm{O}_{3}$ & {$[28]$} \\
1610 & $\mathrm{~N}=\mathrm{O}(\mathrm{s})$ & Bridge-bonded bidentate nitrate on $\mathrm{Al}_{2} \mathrm{O}_{3}$ & {$[28]$} \\
1668 & $\mathrm{~N}=\mathrm{O}(\mathrm{s})$ & Linearly bound $\mathrm{NO}$ on $\mathrm{Pt}$ & {$[29]$} \\
1746 & $\mathrm{~N}=\mathrm{O}(\mathrm{s})$ & Linearly bound $\mathrm{NO}$ on $\mathrm{Pd}^{0}$ & {$[30]$} \\
1828 & $\mathrm{~N}=\mathrm{O}(\mathrm{s})$ & Linearly bound $\mathrm{NO}$ on $\mathrm{Pd}^{+}$ & {$[30]$} \\
1936 & $\mathrm{C}=\mathrm{O}(\mathrm{s})$ & Bridge-bonded $\mathrm{CO}$ on $\mathrm{Pd}_{1}$ & {$[31]$} \\
$2050-2070$ & $\mathrm{C}=\mathrm{O}(\mathrm{s})$ & Linearly bound $\mathrm{CO}$ on $\mathrm{Pt}$ & {$[32]$} \\
2080 & $\mathrm{C}=\mathrm{O}(\mathrm{s})$ & Linearly bound $\mathrm{CO}$ on $\mathrm{Pd}_{2}$ & {$[6,31]$} \\
2260 & $\mathrm{C}=\mathrm{N}(\mathrm{s})$ & Isocyanate $\left(-\mathrm{CNO}\right.$ on $\mathrm{Al}_{2} \mathrm{O}_{3}$ & {$[6,33,31,34]$} \\
$2350-2360$ & $\mathrm{C}=\mathrm{O}(\mathrm{s})$ & Gaseous $\mathrm{CO} \mathrm{O}_{2}$ & {$[29,33,34]$} \\
$3150-3400$ & $\mathrm{~N}-\mathrm{H}(\mathrm{s})(\mathrm{as})$ & $\mathrm{NH}_{3}$ bound to Lewis acid sites & {$[2,35,36]$} \\
\hline
\end{tabular}

considerable amounts of ammonia can be formed over silica, alumina and titania supported platinum and palladium catalysts in a fairly broad temperature interval ranging from 200 to 450 ${ }^{\circ} \mathrm{C}$. With the assumption that no significant storage of $\mathrm{NH}_{3}$ on the catalyst takes place, near complete conversion of NO to $\mathrm{NH}_{3}$ over the $\mathrm{Al}_{2} \mathrm{O}_{3}$ and $\mathrm{SiO}_{2}$ supported catalysts is possible when $\mathrm{H}_{2}$ is directly available in the feed. The decrease in $\mathrm{NH}_{3}$ formation above $425^{\circ} \mathrm{C}$, with no accompanying change in $\mathrm{NO}$ conversion, indicates that ammonia starts to decompose, forming elemental $\mathrm{N}_{2}$ and $\mathrm{H}_{2}$ at high temperatures [16, 37]. We have also shown that oxygen is detrimental to the ammonia formation, however, in some cases a minor oxygen supply may be beneficial. The results that are obtained point towards a dependence on not only the support material of the catalyst but also the type of noble metal for adequate production of the desired $\mathrm{NH}_{3}$. In the following we will discuss the roles of, on one hand, the noble metals and, on the other hand, the support materials for the ammonia formation mechanism.

To allow fair comparison of the influence of the noble metal (Pt or Pd) on the activity for ammonia formation, the molar amount of noble metal was kept constant during catalyst synthesis, i.e. the platinum catalysts were prepared with a noble metal loading of $1.0 \mathrm{wt} . \%$ whilst the palladium catalysts a load- ing of $0.5 \mathrm{wt} \%$. The results from the ICP-OES measurements confirm the targeted loadings. One should notice, however, that the same molar amount of noble metal is not the only criterion for a fair comparison as the precious metal dispersion and/or particle size distribution may be rather different between the different samples, which of course may influence the catalytic properties [22]. This is due to varying degree of interaction between the noble metal and metal oxide support, which is unique in each case. Generally silica is considered to interact more weakly with noble metals than alumina and titania [38]. From the TEM analysis this is recognized by relatively large noble metal particles for the silica samples. Unfortunately we could not make a proper particle size distribution analysis due to the inability to distinguish individual noble metal particles in $\mathrm{Pd} / \mathrm{Al}_{2} \mathrm{O}_{3}$ and the titania supported samples. This is most likely due to small and/or oxidized metal particles resulting in too low contrast/resolution. Interestingly in the case of $\mathrm{Pt} / \mathrm{TiO}_{2}$, although the expected Pt content is confirmed via ICP-EOS analysis, platinum is neither observed by TEM nor EDS analysis. This may suggest that instead of well-dispersed Pt particles, the sample consists of larger particles not identified. This is supported by the presence of the sharp X-ray diffraction peak from metallic Pt (111), but is also confirmed by the in situ DRIFTS 
results showing a very sharp and intense absorption band for linearly adsorbed CO during oxygen-free conditions ( $c f$. Figure 6), which is expected for extended facets [39]. However, despite these differences between the samples it is still possible to compare the types of noble metals and support materials from the point of view of catalyst systems. Furthermore we mention that experiments (not shown) with significantly lower Pt loading gave nearly the same quantitative result, which supports that differences in noble metal dispersion of the present samples is not critical for the conclusions made here. Also, thanks to the in situ DRIFTS experiments the mechanism behind ammonia formation can be discussed in more detail.

The kinetic measurements in the flow reactor clearly show that the type of metal employed in the catalyst formulation has a significant effect on the $\mathrm{NH}_{3}$ formation. At temperatures below $200{ }^{\circ} \mathrm{C}$, when hydrogen is available in the feed, the Pt containing samples produce significantly more $\mathrm{NH}_{3}$ than their $\mathrm{Pd}$ counterparts ( $c f$. Figure 2). On the contrary, below $250{ }^{\circ} \mathrm{C}$ during WGS-assisted reaction conditions, the trend appears to switch so that the Pd containing samples show increased activity as compared to the Pt containing counterparts ( $c f$. Figure 3 ). This trend can also be seen in the steady-state experiments in Figure 5, for which no $\mathrm{NH}_{3}$ is formed over the Pt samples at $250{ }^{\circ} \mathrm{C}$ although the $\mathrm{TiO}_{2}$ and $\mathrm{Al}_{2} \mathrm{O}_{3}$ supported $\mathrm{Pd}$ samples are active under these conditions. This can partly be explained by the enhanced low-temperature WGS activity over Pd compared to that of $\mathrm{Pt}$, and has previously been reported in the literature [17]. It can also be seen that at higher temperature $\left(300{ }^{\circ} \mathrm{C}\right)$ higher amounts of $\mathrm{NH}_{3}$ are formed over the Pt samples. These results are in line with those of Cant et al. [40] who observed that $\mathrm{NO}$ removal over $\mathrm{Pt} / \mathrm{Al}_{2} \mathrm{O}_{3}$ in the presence of $\mathrm{H}_{2}$ and $\mathrm{CO}$ is only evident above $220{ }^{\circ} \mathrm{C}$. The authors suggested that $\mathrm{Pt}$ and Pd surfaces are more prone to be covered by $\mathrm{CO}$ than NO and that this effect is more pronounced on Pt than Pd. Our in situ DRIFTS results support this suggestion as the build-up of linearly adsorbed CO as the S-value is lowered is more pronounced and occurs at higher S-values for the Pt samples than for the Pd samples. According to Cant et al. [40], this surface coverage is detrimental to $\mathrm{NO}_{x}$ reduction since the surface becomes predominantly covered by $\mathrm{CO}$, which displaces NO and hinders the dissociative adsorption of $\mathrm{H}_{2}$ required for the reduction of NO. Once hydrogen is dissociated, the $\mathrm{H}$ adatoms are considered to facilitate the reduction of $\mathrm{NO}$ by removal of $\mathrm{O}$ adatoms from dissociated NO or by hydrogen-assisted NO dissociation. Macleod et al. [41] also reported that the presence of $\mathrm{CO}$ has a negative effect on the reduction of NO on Pt, shifting the activity window for NO reduction towards higher temperatures. Moreover, they also showed that the presence of $\mathrm{CO}$ has a beneficial effect on the reduction of $\mathrm{NO}$ with $\mathrm{H}_{2}$ over Pd systems. This can explain why reduced activity is observed over Pt-containing samples during the steady-state WGS assisted reactions at $\mathrm{S}=0.33$ as compared to when a slight $\mathrm{O}_{2}$ availability is present $(S=0.53)$. The presence of metallic palladium, $\operatorname{Pd}^{0}$, in excess oxygen is consistent with previously reported results by Miller et al. [30]. In their work the authors suggest that this site is responsible for the oxidation of $\mathrm{CO}$ to $\mathrm{CO}_{2}$ and since the vibration from this species disappeared below the stoichiometric point for $\mathrm{CO}$ oxidation (shifting instead towards $\mathrm{Pd}^{+}$), this suggestion seems reasonable.

Turning the focus on the role of the support material, it is clear that alumina and titania generate the most of the discussion in the present study and are probably the most interesting materials for future work. Also, as mentioned in the Introduction, Macleod et al. [2] proposed that $\mathrm{Al}_{2} \mathrm{O}_{3}$ enhances the hydrolysis of surface-bound cyanate (-NCO) groups to $\mathrm{NH}_{3}$ whilst $\mathrm{TiO}_{2}$ supports promote the formation of -NCO groups. Hence, we focused the in situ DRIFTS experiments on the WGS-assisted $\mathrm{NH}_{3}$ formation over $\mathrm{Al}_{2} \mathrm{O}_{3}$ and $\mathrm{TiO}_{2}$ supported 
catalysts, specifically addressing the influence of the stoichiometric number of the feed.

Since it is thought that one route for $\mathrm{NH}_{3}$ formation proceeds via direct reaction of $\mathrm{H}_{2}$ with adsorbed $\mathrm{NO}[11,15]$, the reduced $\mathrm{NH}_{3}$ formation observed over the $\mathrm{TiO}_{2}$ samples when $\mathrm{H}_{2}$ is available in the feed during the temperature programmed reaction experiments may be related to the reduced surface area caused as a result of high-temperature treatment. It is possible that the loss of surface area of the support results in a lowered NO adsorption capacity thus resulting in less NO available to react with $\mathrm{H}_{2}$. Upon observation of the DRIFT spectra obtained for both the $\mathrm{TiO}_{2}$ samples, the intensity of the observed absorption bands for the $\mathrm{Pd} / \mathrm{TiO}_{2}$ sample is very low. Again, this is most likely related to the reduced surface area upon calcination, possibly suggesting that many of the active Pd particles present in the sample have been engulfed by the support during the growth of $\mathrm{TiO}_{2}$ particles. This makes the active sites increasingly difficult to reach, reducing the adsorption capacity for reactant molecules. Another feature of the DRIFT spectra, which supports the explanation that it is the limited adsorption capacity of this sample which negatively affects its activity, is the absence of absorption bands representative of cyanate groups. Since Macleod et al [2] propose that $\mathrm{TiO}_{2}$ promotes the formation of cyanate groups on its surface, we would have expected to see a more substantial contribution of these peaks to the obtained spectra than those on the $\mathrm{Al}_{2} \mathrm{O}_{3}$ support. However, no such peaks were observed at all, indicating a significant loss of active sites on the sample. From the results in this study, it can be concluded with some confidence that there is more than one route possible for $\mathrm{NH}_{3}$ formation using $\mathrm{NO}, \mathrm{CO}$ and $\mathrm{H}_{2} \mathrm{O}$ as reactants since $\mathrm{NH}_{3}$ was detected over the $\mathrm{TiO}_{2}$ supported samples despite the absence of cyanate groups.

An interesting trend observed for the $\mathrm{TiO}_{2}$ supported samples is the enhanced activity for $\mathrm{NH}_{3}$ formation when in the presence of some $\mathrm{O}_{2}(\mathrm{~S}=0.53)$ as compared to a total absence (0.33). This can be related to the well recognized strong metal-support interaction of $\mathrm{TiO}_{2}$ supported noble metal catalysts, which has been reported extensively in literature [42, 43, 44]. Under reducing conditions at high temperature $\left(>300{ }^{\circ} \mathrm{C}\right)$, reduced titania $\left(\mathrm{TiO}_{x}\right)$ can migrate onto the surface of the noble metal crystallites thereby strongly modifying or even covering active sites. This alters the chemisorption properties of the catalyst, possibly making the adsorption and dissociation of NO a limiting factor for the $\mathrm{NH}_{3}$ formation. In the presence of $\mathrm{O}_{2}$ this effect is dampened, which promotes formation of ammonia.

During the WGS-assisted experiments, a clear difference in activity between the $\mathrm{Al}_{2} \mathrm{O}_{3}$ and $\mathrm{SiO}_{2}$ supported samples is observed, as compared to the very similar behaviour they exhibit when hydrogen is available in the feed gas. This difference in activity can be due to $\mathrm{Al}_{2} \mathrm{O}_{3}$ sites that contribute towards rapid hydrolysis of cyanate groups (-NCO) to $\mathrm{NH}_{3}$ as proposed by Macleod et al [2] but can also be ascribed to the enhanced $\mathrm{H}_{2}$ formation ability during the WGS reaction itself over $\mathrm{Al}_{2} \mathrm{O}_{3}$ compared to $\mathrm{SiO}_{2}$ as observed in Figure 3c. It is of importance at this point to state that both cyanate hydrolysis and WGS activity seem to have an influence on the $\mathrm{NH}_{3}$ formation during this reaction. The increase in concentration of $\mathrm{CO}_{2}$ observed in Figure $3 b$ compared to Figure 3c, as a result of the addition of NO into the gas feed, may be explained by the hydrolysis of the cyanate groups to form $\mathrm{NH}_{3}$ and $\mathrm{CO}_{2}$ (Eqns 5-8). This explains the enhanced $\mathrm{NH}_{3}$ formation in the temperature range $200-400{ }^{\circ} \mathrm{C}$ as compared to the WGS activity of the samples in this region when the stoichiometric requirement of $\mathrm{H}_{2}$ needed for $\mathrm{NH}_{3}$ formation (Eqn 3) is not met. The results obtained during the in situ DRIFTS experiments over $\mathrm{Al}_{2} \mathrm{O}_{3}$ also support the proposition of $\mathrm{NH}_{3}$ being formed by hydrolysis of cyanates since, as previously mentioned, an initial increase in intensity of cyanate vibration followed by a decrease can be observed. 
The decrease in cyanate intensity is also accompanied by an increase in the intensity of the $\mathrm{NH}_{3}$ stretching region.

During the steady-state experiments, when the effect of the stoichiometric number on the formation of $\mathrm{NH}_{3}$ was investigated, 500 ppm $\mathrm{O}_{2}$ was chosen as the most significant concentration to focus the experiment around since it is the stoichiometric concentration required for complete oxidation of $\mathrm{H}_{2}$ to $\mathrm{H}_{2} \mathrm{O}$, a factor which was thought to be the limiting factor for the formation of $\mathrm{NH}_{3}$ in the presence of $\mathrm{O}_{2}$. It can be seen that $\mathrm{NH}_{3}$ formation begins when there is insufficient $\mathrm{O}_{2}$ available for the total oxidation of $\mathrm{H}_{2}$, suggesting that this is indeed a limiting factor in the production of $\mathrm{NH}_{3}$ over the catalysts. It is also evident that $\mathrm{NH}_{3}$ formation is possible at slightly higher oxygen concentrations (S-values) when hydrogen is directly available in the feed as compared to WGS reaction conditions. This may be explained by the fact that, in the case of the WGS reaction, there is more than one reductant that can be oxidized over the catalyst. Due to the presence of $\mathrm{CO}$, it may be even more necessary to limit the presence of $\mathrm{O}_{2}$ in the system since it has such a strong impeding effect on the production of $\mathrm{NH}_{3}$. The proposal that the oxidation of $\mathrm{CO}$ to $\mathrm{CO}_{2}$ and hence limitation of $\mathrm{H}_{2}$ formation as a result of the presence of oxygen in the feed being the main cause of $\mathrm{NH}_{3}$ suppression seems viable from the DRIFT spectra obtained. This can be said because as the intensity of the $\mathrm{CO}_{2}$ vibration decreases, a growth in intensity of the $\mathrm{NH}_{3}$ stretching region is observed. However, since isocyanate hydrolysis is an alternative pathway for the formation of $\mathrm{NH}_{3}$ which has led to much discussion in this work, the absence of peaks representative of adsorbed -CNO whilst in the presence of excess $\mathrm{O}_{2}$ should not be ignored. This indicates that an additional explanation for reduced activity in the presence of excess $\mathrm{O}_{2}$ is the inhibition of the formation of isocyanate surface species.

\section{Conclusions}

This study shows that under oxygen deficient conditions it is possible to form significant amounts of $\mathrm{NH}_{3}$ from nitric oxide and $\mathrm{H}_{2}$ or water via the WGS reaction over silica, alumina and titania supported platinum and palladium in the temperature interval $200-450{ }^{\circ} \mathrm{C}$. However, the formation of ammonia is considerably supressed in the presence of $\mathrm{O}_{2}$. The $\mathrm{Al}_{2} \mathrm{O}_{3}$ supported Pd stands out as a promising material for passive SCR applications not only because it is active over a broad temperature range when $\mathrm{H}_{2}$ is directly available in the gas feed, but also due to high activity for the WGS assisted reaction, exhibiting a lower light-off temperature than its Pt-containing counterpart.

In situ DRIFT spectroscopy experiments support that when water is used as the source of hydrogen, there is more than one reaction route possible for $\mathrm{NH}_{3}$ formation; direct reaction of $\mathrm{H}_{2}$ with stored NO but also hydrolysis of cyanate groups. It also shows that the inhibition of the water-gas-shift reaction due to the presence of oxygen in the feed is responsible for $\mathrm{NH}_{3}$ suppression over the investigated catalysts.

Concerning the $\mathrm{TiO}_{2}$ samples in this investigation, these need to be thermally stabilised in order to be suitable for use in automotive applications as it seems that the formation of large $\mathrm{TiO}_{2}$ particles leads to low activity. Stabilisation would also be necessary in order to successfully characterise the mechanisms behind $\mathrm{NH}_{3}$ formation at high temperature.

\section{Acknowledgments}

This work was financially supported by the Swedish Energy Administration through the FFI program and the Competence Centre for Catalysis, which is financially supported by Chalmers University of Technology, the Swedish Energy Agency and the member companies: AB Volvo, ECAPS AB, Haldor Topsøe A/S, Volvo Car Corporation, Scania CV AB, and Wärtsilä Finland Oy. 


\section{References}

[1] M. A. Gómez-García, V. Pitchon, and A. Kiennemann Environ. Int., vol. 31, pp. 445-467, 2005.

[2] N. Macleod, R. Cropley, J. M. Keel, and R. M. Lambert J. Catal., vol. 221, pp. 20-31, 2004.

[3] Y. Liu, M. P. Harold, and D. Luss Appl. Catal. B: Environ., vol. 121, pp. 239-251, 2012.

[4] S. M. Park, M.-Y. Kim, E. S. Kim, H.-S. Han, and G. Seo Appl. Catal. A: Gen., vol. 395, pp. 120-128, 2011.

[5] A. Lindholm, N. Currier, J. Li, A. Yezerets, and L. Olsson J. Catal., vol. 258 , pp. 273-288, 2008.

[6] N. Macleod and R. M. Lambert Appl. Catal. B: Environ., vol. 46, pp. 483495, 2003.

[7] C. Ciardelli, I. Nova, E. Tronconi, D. Chatterdee, T. Burkhardt, and M. Weibel Chem. Eng. Sci., vol. 62, pp. 5001-5006, 2007.

[8] P. Forzatti, L. Lietti, I. Nova, and E. Tronconi Catal. Today, vol. 151, pp. 202-211, 2010.

[9] M. Koebel, M. Elsener, and M. Kleemann Catal. Today, vol. 59, pp. 335345, 2000.

[10] G. Li, C. Jones, V. Grassian, and S. Larsen J. Catal., vol. 234, pp. 401$413,2005$.

[11] P. R. Dasari, R. Muncrief, and M. P. Harold Catal. Today, vol. 184, pp. 43-53, 2012.

[12] N. V. Heeb, A.-M. Forss, S. Brühlmann, R. Lüscher, C. J. Saxer, and P. Hug Atm. Environ, vol. 40, pp. 5986-5997, 2006.

[13] T. D. Durbin, J. T. Pisano, T. Younglove, C. G. Sauer, S. H. Rhee, T. Huai, J. W. Miller, G. I. MacKay, A. M. Hochhauser, M. C. Ingham, R. A. Gorse, L. K. Beard, D. DiCicco, N. Thompson, R. J. Stradling, J. A. Rutherford, and J. P. Uihlein Atmos. Environ., vol. 38, pp. 2699-2708, 2004.

[14] C. D. DiGulio, J. A. Pihl, J. E. Parks II, M. D. Amiridis, and T. J. Toops Catal. Today, vol. 231, pp. 33-45, 2014.

[15] F. Can, X. Courtois, S. Royer, G. Blanchard, S. Rousseau, and D. Duprez Catal. Today, vol. 197, pp. 144-154, 2012.

[16] R. D. Clayton, M. P. Harold, and V. Balakotaiah Appl. Catal. B: Environ, vol. 81, pp. 161-181, 2008.

[17] N. W. Cant, D. C. Chambers, and I. O. Y. Liu Appl. Catal. B: Environ, vol. 46, pp. 551-559, 2003.

[18] M. L. Unland Science, vol. 179, pp. 567-569, 1973.

[19] S. Brunauer, P. H. Emmett, and E. Teller J. Am. Chem. Soc., vol. 60, pp. 309-319, 1938.

[20] H. Kannisto, X. Karatzas, J. Edvardsson, L. J. Pettersson, and H. H. Ingelston Appl. Catal. B: Environ., vol. 104, pp. 74-83, 2011.
[21] J. C. Summers and K. Baron J. Catal., vol. 57, pp. 380-389, 1979.

[22] S. K. Matam, E. V. Kondratenko, M. H. Aguirre, P. Hug, D. Rentsch, A. Winkler, A. Weidenkaff, and D. Ferri Appl. Catal. B: Environ., vol. 129, pp. 214-224, 2013.

[23] C. R. Bickmore, K. F. Waldner, R. Baranwal, T. Hinklin, D. R. Treadwell, and R. M. Lain J. Eur. Ceram. Soc., vol. 18, pp. 287-297, 1998.

[24] H. A. Benesi and A. C. Jones J. Phys. Chem., vol. 63, pp. 179-182, 1959.

[25] S. Yamazoe, T. Okumura, Y. Hitomi, S. T, and T. Tanaka J. Phys. Chem., vol. 111, pp. 11077-11085, 2007.

[26] S. M. Lee and S. C. Hong Appl. Catal. B: Environ., vol. 163, pp. 30-39, 2015.

[27] C. Morterra and G. Magnacca Catal. Today, vol. 27, pp. 497-532, 1996.

[28] T. J. Toops, D. B. Smith, W. S. Epling, J. E. Parks, and W. P. Partridge Appl. Catal. B: Environ., vol. 58, pp. 255-264, 2005.

[29] S.-H. Chien, M.-C. Kuo, C.-H. Lu, and K.-N. Lu Catal. Today, vol. 97, pp. $121-127,2004$.

[30] D. D. Miller and S. S. C. Chuang J. Taiwan Inst. Chem. E., vol. 40, pp. 613-621, 2009.

[31] S. Almusaiteer and S. S. C. Chuang J. Catal., vol. 201, pp. 189-201, 1999.

[32] I. Nova, L. Lietti, P. Forzatti, F. Prinetto, and G. Ghiotti Catal. Today, vol. 151 , pp. 330-337, 2010.

[33] C. Neyertz, D. Volpe, D. Perez, I. Costilla, M. Sanchez, and C. Gigola Appl. Catal. A: Gen., vol. 368, pp. 146-157, 2009.

[34] Y. Ji, T. J. Toops, J. A. Pihl, and M. Crocker Appl. Catal. B: Environ., vol. 91, pp. 329-338, 2009.

[35] T. Nanba, F. Meunier, C. Hardacre, J. P. Breen, R. Burch, S. Masukawa, J. Uchisawa, and A. Obuchi J. Phys. Chem. C., vol. 112, pp. 1815718163, 2008.

[36] L. Castoldi, R. Bonzi, L. Lietti, P. Forzatti, S. Morandi, G. Ghiotti, and S. Dzwigaj J. Catal., vol. 282, pp. 128-144, 2011.

[37] J. Choi, W. P. Partridge, J. A. Pihl, M.-Y. Kim, P. Koci, and C. S. Daw Catal. Today, vol. 184, pp. 20-26, 2012.

[38] A. Vazquez-Zavala, J. García-Gómez, and A. Gómez-Cortés Appl. Surf. Sci., vol. 167, pp. 177-183, 2000.

[39] A. Priebe, G. Fahsold, and A. Pucci J. Phys. Chem., vol. 108, pp. 18174 18178, 2004.

[40] N. W. Cant, D. C. Chambers, and I. O. Y. Liu J. Catal., vol. 231, pp. 201$212,2005$.

[41] N. Macleod and R. M. Lambert Appl. Catal. B: Environ., vol. 35, pp. 269$279,2002$.

[42] J. C. Colmenares, A. Magdziarz, M. A. Aramendia, A. Marinas, M. J. M, F. J. Urbano, and J. A. Navio Catal. Commun., vol. 16, pp. 1-6, 2011. 
[43] M. S. Spencer J. Catal., vol. 93, pp. 216-223, 1985.

[44] O. Dulub, W. Habenstreit, and U. Diebold Phys. Rev. Lett., vol. 84, pp. 3646-3649, 2000. 